\title{
Evaluation of Patients on the Deceased Kidney Waiting List of Bursa Uludag University Medical Faculty according to Gender, Age, Blood Type and Renal Replacement Therapies
}

Ersin ELGINN ${ }^{1}$, Mehmet Fethullah AYDIN², Abdulmecit YILDIZ², Ayşegül ORUÇ², Suat AKGÜR², Mehmet SEZEN $^{2}$, Mehmet ÇAĞATAY ÇIÇEK ${ }^{3}$, Kadir Ömür GÜNSEREN ${ }^{3}$, İbrahim Ethem ARSLAN ${ }^{4}$, Sahriye KESKIN $^{1}$, Rafet OFLAZ ${ }^{1}$, Kerem SELIMOĞLU ${ }^{1}$, İlknur ARSLAN ${ }^{1}$, Alparslan ERSOY ${ }^{2}$

\footnotetext{
${ }^{1}$ Bursa Uludağ University Faculty of Medicine, Organ Transplantation Center, Bursa, Turkey

${ }^{2}$ Bursa Uludağ University Faculty of Medicine, Division of Nephrology, Bursa, Turkey

${ }^{3}$ Bursa Uludağ University Faculty of Medicine, Department of Urology, Bursa, Turkey

${ }^{4}$ Health Sciences University Bursa Yüksek İhtisas Training and Research Hospital, Urology Clinic, Bursa, Turkey
}

Turk J Int Med 2021;3(Supplement 1):S27-S28 DOI: $10.46310 /$ tjim. 876465

Keywords: EDC, Kidney Failure, Right to Health

In Turkey, there are 22,953 end-stage kidney disease patients on the national deceased kidney waiting list. ${ }^{1}$ According to the 2019 Registry Report of the Turkish Society of Nephrology, the number of patients receiving hemodialysis (HD) and peritoneal dialysis (PD) treatment is $64,633 .^{2}$ However, patients registered on the national kidney waiting list consist of preemptive, $\mathrm{PD}$, and HD patients. Due to the increase in the average life expectancy of the elderly population in our country, chronic kidney disease and comorbid diseases are increasing day by day.

This retrospective study evaluated the patients' characteristics on the deceased kidney waiting list from our kidney transplant center. Our center's patient data were obtained from Transplantation Dialysis Monitoring System records. Turkey's general patient data were obtained from the Turkish Statistical Institute and the 2019 Registry Report of the Turkish Society of Nephrology.

In our center, the number of patients on the deceased donor kidney waiting list was 420 (HD 301, PD 24, preemptive 95). The number of female patients was $162(38.6 \%)$, and the number of male patients was $258(61.4 \%)$. The age distribution of the patients; 0-9: 1.1\%, 10-19: 3\%, 20-29: 4.4\%, 30-39: $11.6 \%, 40-49: 20 \%, 50-59: 24.4 \%, 60-69$ : 26.8\%, 70-79: 7.8\%, and 80-89: 0.2\%. The blood group distribution of patients was consistent with Turkey's general data [0 Rh (+): 26.7\%, $0 \mathrm{Rh}(-)$ : $3.1 \%$, A Rh (+) 43.3\%, A Rh (-) 5.7\%, B Rh (+) $11 \%$, B Rh (-) $1.7 \%$, AB Rh (+) $8.1 \%$, and AB Rh (-) $0.5 \%$. The number of male patients was higher than female patients in other age groups except the 


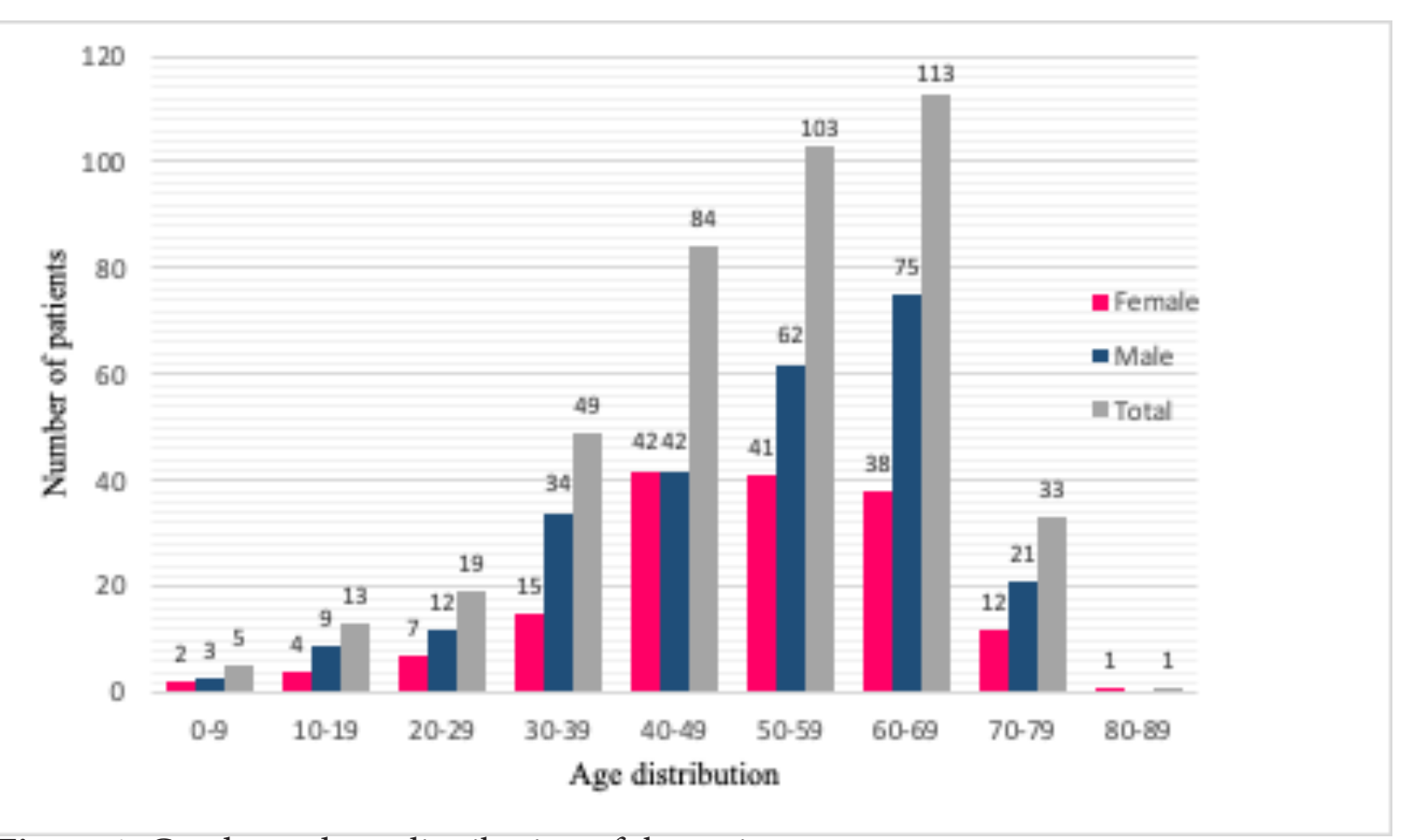

Figure 1. Gender and age distribution of the patients.

40-49 and 80-89 age range (Figure 1). Our patients' distribution by gender and kidney replacement therapies was in line with the 2019 Registry Report of the Turkish Society of Nephrology.

An increase in comorbid diseases and kidney failure in advanced age also increases health expenditures. The Republic of Turkey Ministry of Health aims to increase the awareness of kidney disease and the rate of early diagnosis with the "Turkey Kidney Diseases Prevention and Control Program.". 3 In our center, the highest number of patients on the deceased kidney waiting list was observed in the age range of 60-69, 50-59, and 4049 , respectively. Physical quality of life worsens as the dialysis period prolongs and the patient ages. Therefore, elderly HD patients need more social and mental support. ${ }^{4}$ The age of the donor being 60 years and above is one of the extended donor criteria (EDC). ${ }^{5}$ Using kidneys with advanced age and EDC criteria in candidates of similar age may increase both patient and graft survival and physical quality of life. For this reason, the authorized persons should be developed policies to ensure the transplantation of EDC grafts to patients who will benefit most.

\section{Conflict of Interests}

Authors declare that there are none.

\section{Acknowledgment}

This study has been presented in $17^{\text {th }}$ Uludag Internal Medicine National Winter Congress, $6^{\text {th }}$ Bursa Family Medicine Association National Congress, $11^{\text {th }}$ Uludag Internal Medicine Nursing Congress, 5-7 March 2021, Bursa, Turkey.

\section{References}

1. TTIDS. ORGAN KDS 2021. Böbrek Nakli Bekleyenler. Available at: https://organkds.saglik.gov.tr/dss/ PUBLIC/WL_Kidney.aspx. Accessed February 04, 2021.

2. Türk Nefroloji Dernegi Registry Raporları. Registry 2019. Available at: http://www.nefroloji.org.tr/icerik. php?gid=88. Accessed February 02, 2021.

3. Türkiye Böbrek Hastalıkları Önleme ve Kontrol Programı (2014-2017). T.C. Saglık Bakanlıg1 yayın no: 946, Ankara: An11 Reklam Matbaa Ltd. Sti., 2014:1-62. Available at: http://www.nefroloji.org.tr/pdf/Turkiye_ Bobrek_Hastaliklari_Onleme_ve_Kontrol_Programi. pdf. Accessed February 03, 2021.

4. Ishiwatari A, Yamamoto S, Fukuma S, Hasegawa T, Wakai S, Nangaku M. Changes in quality of life in older hemodialysis patients: A cohort study on dialysis outcomes and practice patterns. Am J Nephrol. 2020;51(8):650-658. doi: 10.1159/000509309.

5. Metzger RA, Delmonico FL, Feng S, Port FK, Wynn JJ, Merion RM. Expanded criteria donors for kidney transplantation. Am J Transplant. 2003;3 Suppl 4:11425. doi: $10.1034 /$ j.1600-6143.3.s4.11.x. 